\title{
Labour relations in comparative perspective - special focus on the SME sector ${ }^{*}$
}

\author{
Csaba Makó, Péter Csizmadia, Miklós Illéssy ${ }^{* *}$
}

The evolution of the view and practice of "social partnership" is one basic element in the construction of the European Union. The paper gives an overview on the key actors and institutions of Labour Relations System (LRS) with special focus on the micro- small and medium sized enteprises (SME). In the first section, the author describes the key social partners and institutions of the LRS in the countries participating in an international research project carried out in 2003-2006 and supported by the Leonardo Programme of the EU (Annex 1). The second section of the paper deals with the particular features of the LRS in the SME sector. The strong "informality" of social dialogue is the key institutional pattern of LRS in the SME sector.

Die Evolution der Ansicht und Anwendung von ,, sozialen Partnerschaften “ ist ein Basiselement in der Konstruktion der Europäischen Union. Der Aufsatz gibt einen Überblick über die Hauptakteure und Institutionen des Labour Relations System (LRS), mit dem Augenmerk auf kleine und mittelgrosse Unternehmen (SME). Im ersten Abschnitt beschreibt der Autor die wichtigen sozialen Partner und Institutionen der LRS in den beteiligten Ländern an einem internationalen Forschungsprojekt in 2003-2006, unterstützt vom Leonardo Programm der EU (Annex 1). Der zweite Teil behandelt die spezifischen Eigenschaften des LRS im SME Sektor. Die ausgeprägte „Informalität“ des sozialen Dialogs ist ein wichtiges institutionelles Muster der LRS im SME Sektor.

Key words: Labour Relations System, Social Actors and Institutions, Collective Bargaining, Works Council, Informal Regulation, SME.

* Manuscript received: 20.01.06. accepted: 11.04 .06 (1 revision)

** Csaba Makó, Research Director, Institute of Sociology Hungatian Academy of Sciences, Budapest. Main research areas: Innovations and learning process, labour relations in international perspective and the emerging new patterns of work organisation and management related to the use of ICT. Corresponding address: Mako@socio.mta.hu

Péter Csizmadia, Research Associate, Institute of Socioogy of the Hungarian Academy of Sciences; PhD-student, Department of Sociology and Social Policy,Corvinus University, Budapest. Corresponding address: pcsizmadia@socio.mta.hu.

Miklós Illéssy, Research Associate, Institute of Sociology of Hungarian Academy of Sciences; PhD-student, Department of Sociology and Social Policy, Corvinus University Budapest. Corresponding address: 1llessy@socio.mta.hu 


\section{Foreword}

The aim of the project supported by the Leonardo programme of the European Commission was to develop a research-based international comparative training curriculum about the SME sectors in eight European participant countries: Belgium, France, Germany, Hungary, Poland, Slovakia, Spain and the UK. The results of the fist project phase is summarised in an International Comparative Report (CR). This analysis is focusing on the such social regulatory institutions of firms' behaviour as the Labour Relations System (LRS).

\section{Introduction: some remarks on the varieties of european industrial relations}

Prior to identify and understand the main features and trends in the development of labour relations ${ }^{1}$, we would like to stress the core importance of social dialogue in the construction of the European social and economic space. Adopting the importance of the partnership approach both at EU- and national level, we recognise the joint responsibility of various actors for the necessary social and economic changes within the context of intense globalised competitive pressure.

In mapping the changing diversity of the characteristics of the Labour Relations System (LRS), we would like to use the following analytical dimensions:

1. Social actors, that is trade unions, employers' organisations, and other types of interest representatives associations.

2. Institutions, that is collective agreement (e.g. coverage rate, level of coordination), wage bargaining, institutions of employees' participation (e.g. works council), national tripartite institutions, industrial actions (e.g. strikes).

Beside the descriptive analyses of the roles of actors and institutions, we intend to identify and illustrate several trends (decentralisation, changing forms of coordination and cooperation, etc.) which are shaping the present and future practice of labour relations at European and country level, especially in the SME sector. The first and second sections of this analysis provide a general overview of the actors (e.g. interest representative organisations both of employees and employers) and the formal institutions of the LRS (e.g. collective bargaining

1 In the standard publications, the term of 'industrial relations' is used almost exclusively. Contrary to this practice, we intend to use 'labour relation' instead of the notion of 'industrial relations'. In our view, the term of 'labour relations' is seem to us as more general and it indicates the growing importance of the idea and practice of social partnership not only in the field of traditional industrial economic activities but in the service sector and especially in the fast growing branches of the New Economy. 
coverage rate, etc.). The third section is focusing the on the labour relations in the SMEs sector.

\section{Actors and institutions: An international comparison at european and country levels}

\subsection{Trade unions and institution (works council) of employees' participation}

Before giving a general outline on the main characteristics of actors and institutions it is necessary to make distinction among national LRS according the roles of the trade unions and the employees' participation in the firm. According to these two dimensions the following patterns should be distinguished (Industrial Relation in Europe, 2004: 21):

1. The 'single channel system', where the workplace representation of employees (i.e. rights to information, consultation or co-determination) is controlled exclusively by the trade unions. The advantage of this system for employees' representation relies in its simplicity and the lack of rivalry between the two channels of employees' workplace representation (e.g. Poland and UK illustrate well the 'single channel systems', but based on the voluntary principle.) However, the 'single channel system' of employees' representation does not deal with the problems of non-union members, and employees in nonunionised firms are excluded from the collective representation (e.g information, consultation and/or co-decisions).

2. The so-called 'mixed channel system' in which the workplace representation of the non-union members is achieved by the trade unions or through a supplementary channel in the non-unionised companies (e.g. in Poland the government supports the establishment of works councils, independent from the trade unions because of the opposition of both certain unions and employers.)

3. In the case of the of the 'dual channel system' the Labour Law provides a separate channel of employees' participation - additional to trade union representation. This duality of LRS characterises the majority of countries participating in the Leonardo Project: Belgium, France, Germany, Hungary, Slovakia, Spain and Poland (in this latter country works councils exist only in state owned firms). In the countries where the 'dual channel system' operates, a kind of rivalry can be identified between the works council and trade unions. (Makó 2001.) However, "in reality lay union officials and representatives tend to play a leading role in the councils and councils may be a recruitment ground for trade unions. Works councils tend to be highly unionised and in council elections the trade union candidates tend to attract votes from members and nonmembers alike. Another encouraging sign is that voter turnout in workplace election tends to be high, between 65 and $85 \% \ldots$ in the new Member States 
(NMS) only ... in Hungary and Slovenia are councils comparable with the fullyfledged types in EU-15." (Industrial Relations in Europe 2004:21-23).

This section provides an overview on the trade union density rates and on the union structures and affiliation. In relation with the density rates, significant differences were identified betweens such global economies as Europe, USA and Japan but among the countries of the EU 25 as well. As we expected, the union density rate (2001) is much higher in the EU (25) $26.4 \%$ in comparison with USA $12.9 \%$ and Japan $20.9 \%$. Among the countries participating in the Leonardo project substantial differences were found, too. The highest unionisation rate was registered in Belgium $55.8 \%$ (2001) followed by Slovakia $35.4 \%$ (2002) and UK $30.4 \%$ (2002), than in Germany $23.2 \%$ (2002) and Hungary $19.9 \%$ (2002). The lowest trade union density rates were identified in Poland $14.7 \%$ (2001) and France $9.7 \%$ (2001). In addition, we have to note that the union density rates are varying substantially by the private and the public sectors. For example Hungary, France, Poland and Slovakia more than every second union members are working in the public sectors. The higher density rates in the public sectors are explained partly by the institutional heritage of the past in the post-socialist countries became EU members ( $1^{\text {st }}$ May 2004) and the difficulties of trade unions to hire members in the private sector, especially in the SME sector and in the newly established firms (i.e. companies established in the form of the "green-field" investments). (Makó-Novoszáth, 1995.) (See Table $1 !)$

Table 1. Trade union density rates and membership composition, 1995-2002

\begin{tabular}{|l|c|c|c|c|c|c|}
\hline \multirow{2}{*}{} & \multicolumn{3}{|c|}{ Union density rates } & Change & \multicolumn{2}{c|}{ Share of all members } \\
\cline { 2 - 7 } & $\mathbf{1 9 9 0}$ & $\mathbf{1 9 9 5}$ & $\mathbf{2 0 0 2}$ & $\mathbf{1 9 9 5 - 2 0 0 2}$ & Female & Public \\
\hline Belgium & 53.9 & 55.7 & $55.8^{*}$ & +0.1 & n. d. & n. d. \\
\hline France & 10.1 & 9.8 & $9.7^{*}$ & -0.1 & $48.3^{* *}$ & $66.3^{* *}$ \\
\hline Germany & 31.2 & 29.2 & 23.2 & -0.9 & 31.2 & 39.3 \\
\hline Spain & 14.7 & 16.3 & $\begin{array}{c}14.9 \\
(1999)\end{array}$ & -0.1 & n. d. & $31.2^{* *}$ \\
\hline Hungary & n. d. & 63.4 & 19.9 & -6.2 & $48.7^{* *}$ & $70.3^{* *}$ \\
\hline Poland & n. d. & 32.9 & 14.7 & -18.2 & $55.1^{* *}$ & $76.6^{* *}$ \\
\hline UK & 78.7 & 57.3 & 35.4 & -43.3 & $49.6^{* *}$ & $70.9^{* *}$ \\
\hline $\begin{array}{l}\text { Average EU- } \\
25^{* * *}\end{array}$ & 39.3 & 34.1 & 30.4 & -8.9 & 43.7 & 47.4 \\
\hline $\begin{array}{l}\text { Average EU- } \\
15^{* * *}\end{array}$ & n. d. & 32.6 & $26.4^{*}$ & -6.2 & n. d. & n. d. \\
\hline $\begin{array}{l}\text { Average EU- } \\
10^{* * *}\end{array}$ & n. d. & 42.7 & $20.4^{*}$ & -22.3 & n. d. & n. d.. \\
\hline
\end{tabular}

NB: Density rates for EU-15 countries are standardised, i.e. without unemployed and selfemployed, retired employees and student members, along the model in B. Ebbinghaus and J. Visser (2000) The societies of Europe, quoted by 'Industrial Relations in Europe: 2004', p. 
19. In the case of the UK, figures are calculated from the Labour Force Survey. Elsewhere they are recalculated from administrative sources. See also OECD, Employment Outlook 2004, Chapter 3 ('Wage-setting outcomes and institutions'), Paris, July 2004. The EU-10 figures are non-standardised and follow nationally based statistics collected by the Institut des Sciences du Travail of the Universite Catholique de Louvain, Monographs on the Situation of social partners in the candidate countries, Brussels, December 2003, a research project conducted on behalf of the Employment and Social Affairs DG of the European Commission. Quoted by 'Industrial Relations in Europe', 2004: 19. Table 1 is an edited version of the original one containing data only for countries involved in the Leonardo Project.

*Data available only from 2001.

** The data on membership composition (share of female members; share of members in the public sector) are calculated from sample surveys of the International Social Science Programme (ISSP) and relate to 1998.

***Weighted averages. In the case of missing data, the nearest year is taken into account.

Evaluating the patterns of trade union structures and affiliations in the countries involved in the Leonardo Project we distinguished the following two structural settings. In the first group of the countries surveyed, "single or dominant" trade union confederation coordinates the activities of the branch organisations. This group of countries comprises Germany, UK and Slovakia. In the second group of countries trade union centres are divided on political and ideological basis. For example in France and Spain "political divide" exist within the broad left or these division, others relate to such ideological orientation as Christian and Social Democratic values. In the such NMS like Hungary and Poland trade union centres have links with both right and left parties (e.g. in Hungary, "National Alliance of Works Councils" has links with the Democratic Forum and the "National Association of Hungarian Trade Unions" maintain rather strong links with the Hungarian Socialist Party.) Further fragmentation of the trade union centres could be observed in some countries. Fore example in France, there are separate centres for managerial and white collar staffs and regional division is noticeable in Spain. (See the Table 2!) ${ }^{2}$

Comparing the patterns of trade union structures, affiliation and characteristics of the recent modernisation of the union organisation (e.g. organisational decentralisation - fragmentation or concentration-merger) we may identify not only contrasting but non-synchronised movements. For example, at the beginning of the XXIst century (2001) in Germany, the autonomous general trade union of white-collar employees merged with the well-known German Confederation of Trade Unions (DGB). A similar major union merger took place in the UK (2002), too. The creation of these 'conglomerate' unions was the

2 Naturally there are other organizational principles of the interest representative organisations. For example in another group of the countries - whose members did not participate in the Leonardo Project - trade union centres are created on the occupational basis (e.g. Finland, Sweden, Denmark etc.). 
answer of the trade unions in the EU-15 countries to the external social and economic changes (e.g. to better cope with the growing need for coordination among trade unions in their confrontation-cooperation with the employers and their associations.) The creation of the 'conglomerate' or 'mega' trade unions should be interpreted as an initiative which may counterbalance the increased discretionary power of employers opened to them by the disintegration of both external and internal constraints.

Table 2. Union structure and affiliation patterns in the EU

\begin{tabular}{|l|c|c|c|c|c|c|}
\hline \multirow{2}{*}{ Country } & \multicolumn{2}{|c|}{ Main union confederations } & \multicolumn{3}{c|}{ Affiliates $^{(\mathbf{( 2 )}}$} \\
\cline { 2 - 7 } & $\mathbf{N}^{\circ}$ & $\begin{array}{c}\text { Main divisions } \\
\text { between } \\
\text { confederations }\end{array}$ & $\begin{array}{c}\text { Share } \\
\text { of } \\
\text { largest }\end{array}$ & $\mathbf{N}^{\circ}$ & $\begin{array}{c}\text { Main divisions } \\
\text { between } \\
\text { confederations }\end{array}$ & $\begin{array}{c}\text { Share of all } \\
\text { members }\end{array}$ \\
\hline Belgium & 3 & $\begin{array}{c}\text { political- } \\
\text { religious }\end{array}$ & 50 & 17 & sector\&status & 2 \\
\hline Germany & $6^{(7)}$ & $\begin{array}{c}\text { polit- } \\
\text { relig\&occup. }\end{array}$ & 28 & 20 & sector & 12 \\
\hline Spain & $2^{(3)}$ & private\&public & 83 & 8 & sector & 17 \\
\hline Hungary & 6 & Political & 41 & 12 & sector & 19 \\
\hline Poland & 3 & Political & 31 & 42 & sector & 1 \\
\hline Slovakia & 1 & $?$ & 43 & 110 & sector\&company & $?$ \\
\hline UK & 1 & $?$ & 84 & 71 & occup.\&sector & 16 \\
\hline
\end{tabular}

${ }^{1}$ Only confederations that organise in several sectors and organise $5 \%$ or more of total membership.

${ }^{2}$ Affiliates or member unions belonging to the largest confederation, only national unions (without local organisations).

${ }^{3}$ Without 36 affiliated unions in Northern Ireland.

${ }^{4}$ Including Turkish Cypriot organisations in Northern Cyprus.

Source: B. Ebbinghaus and J. Visser (2000) The societies of Europe. Trade unions in western Europe since 1945, Palgrave for the main divisions and demarcations in EU-15, updates with information from unions' websites (number of unions) and AIAS union file. For EU-10 Member States, information is obtained from Commission research (UCL). Quoted by Industrial Relations in Europe 2004: 15. Table 2 is an edited version of the original one containing data only for countries involved in the Leonardo Project.

In other words, the merger process of trade unions can be evaluated as an institutional answer of the employees' interest representative organisations to counterbalance the effects of deregulation and the associated destabilisation of rules and procedures of the labour market within and outside firms. The concentration - merger of trade union confederations was partly an attempt to cope with the difficulties resulting from growing internal financial difficulties and the declining trade union membership, too. In the NMS participating in the Leonardo Project we may identify contradictory tendencies. During state socialism employees were forced to be trade union members (e.g. the 
unionisation rate was artificially high, over $90 \%$ ) and the trade unions operating in various economic branches were centralised into one national level centre (e.g. in Hungary this 'mega' centre was called the 'National Council of Trade Unions", in Hungarian: "Szakszervezetek Országos Tanácsa"=SZOT). As a natural reaction to this kind of 'forced' centralization-bureaucratization of trade unions, following the collapse of the state-socialist political-economical regime, in these countries the 'decentralization-fragmentation' became the mainstream tendency. As a result of the breaking down of the former single-centre, we witnessed the emergence of numerous new trade union centres. (See the Table 3.!) However, in the last years there has been an attempt to rationalise and centralise the decentralised and fragmented trade union structures (e.g. in Hungary and Poland).

Table 3. Employees representation and employees rights: single, mixed and dual versions of the LRS

\begin{tabular}{|l|c|c|c|c|c|c|}
\hline \multicolumn{1}{|c|}{ Country } & Basis & Single & Mixed & Dual & $\begin{array}{c}\text { Separate } \\
\text { union } \\
\text { Union } \\
\text { competition } \\
\text { represen- } \\
\text { tation }\end{array}$ \\
\hline Belgium & L\&C & & & Y & Considerable & Normally \\
\hline France & L & & & Y & Very strong & Frequently \\
\hline Germany & L & & & Y & Marginal & Sometimes \\
\hline Spain & L & & & Y & Very strong & Normally \\
\hline Hungary & L & & & Y & Very strong & Normally \\
\hline Poland & L & Y & & & Very strong & N.A. \\
\hline Slovakia & L & & & Y & Marginal & Sometimes \\
\hline UK & A & Some & & & - & N.A. \\
\hline
\end{tabular}

NB: Basis for employees representation rights: central agreement $=\mathrm{C}$; agreement (sector/company) $=\mathrm{A} ;$ law $=\mathrm{L}, \mathrm{Yes}=\mathrm{Y}$, Not applicable $=$ N.A.

Source: Industrial Relations in Europe 2004: 22.

Evaluating the existence of the employees' participation institutions (e.g. works councils) beside the interest representative roles of the trade union, we made distinction between "single", "mixed" and "dual systems". (See Table 4.!) In the in the majority of the Leonardo Project countries the "dual" - Belgium, France, Germany, Hungary and Slovakia - and in Poland, UK the "single" version of the Labour Relations System operates. Even in the countries where works councils as an institution of the employees' information and consultation systems do exist, “... itself differs significantly from country to country in terms of composition, decision-making, election procedures, thresholds, roles and power of the employees representative bodies. (Carley - Baradel - Weltz, 2004:4).

The common elements of the various national works council definitions found in the EU-15 countries summarised in Box 1. 


\section{Box 1. Works councils definition}

Permanent elected bodies of workforce representatives (or occasionally joint committee with employees representatives), set-up on the basis of law or collective agreements with the overall task of promoting cooperation within the enterprise for the benefit of the enterprise itself and employees by creating and maintaining good and stable employment conditions, increasing welfare and security of employees and their understanding of enterprise operations, finance and competitiveness. (Carley et.al 2004:9)

In relation with the establishment of works council, in all European countries with the exception of Sweden - there is a minimum workforce-size threshold for the creation of this institution of the participation. In the Leonardo Project countries, the lowest threshold for works councils' establishment is in Germany 5 employees, in France, Hungary and Spain 50 persons and in Belgium 100 employees. In UK there is no general or statutory system of information and consultation. Beside the "threshold" the other essential feature of works councils is the following: either this institutions of employees' participation is established automatic in all establishment satisfying the threshold criteria or must be triggered (or initiated) by social actors of labour relations (e.g. employees, trade unions or employers). The establishment process in these countries basically automatic as Belgium and France but in the majority of the countries must be initiated by employees/trade unions: Hungary, Germany, Poland and Spain.

In spite the fact that the minimum size in some countries do not exist, hoever in the majority of the countries involved in the Leonardo Project, the threshold is 5, 50 or 100 employees - these workforce-sizes are covering the small and medium-sized firms. In spite the various threshold concerning the establishment of works councils, this important participatory forum is dominant mainly in the large firms (LSE). Even the law provides basis for works councils in such countries as Germany, France, Hungary and Spain, in the SMEs only tiny minority of firms establish works councils. "In Germany, for example, the law provides statutory rights in firms with five or more employees. The establishment of a works council is not mandatory and according to survey figures from 2002, works councils cover just $11 \%$ of all firms and $50 \%$ of all employees within the law's scope. Coverage is related to the size and the age of the firm, with smaller and newer firms much less likely to have established a works council... In France, the Ministry of Labour estimates that of small firms (10-19 employees) less than $20 \%$ have a form of workplace representation for employees. This percentage increases to $56 \%$ for firms with 20-49 employees and to $90 \%$ in firms with more than 50 employees." (Industrial Relations in Europe 2004:22.) The situation is rather similar in Hungary. However, the relation between the size of the firms and the existence of works councils call attention to another vital issue. The rate of the presence of the works councils has strong relations with the trade union presence in the firms surveyed. According to the date of a statistically representative survey carried out in 2002 in Hungary, the share of works councils, trade unions and collective agreements 
are indicating the similar trend: their share is increasing with the size of the firms. (See the Table 4.!)

The statistical analysis on the works councils does not provide information on the difficulties of everyday company practice related to the function of this employees' participatory institution. For example, in countries where the labour code guarantees the rights of works councils (and their members) in regulating the fields of co-decision (e.g. social infrastructure), these rights are sometimes violated even in large firms operating in such very established sector as chemical industry.

Table 4. Distribution of works councils, trade unions and collective agreements by size category of firms in the manufacturing sector in hungary (2002)

\begin{tabular}{|l|c|c|c|c|c|c|c|}
\hline \multirow{2}{*}{$\begin{array}{l}\text { Size of the firm } \\
\text { (persons) }\end{array}$} & \multirow{2}{*}{$\begin{array}{c}\mathbf{N}^{\circ} \text { of } \\
\text { responders }\end{array}$} & \multicolumn{2}{|c|}{ Works councils } & \multicolumn{2}{c|}{ Trade Unions } & \multicolumn{2}{c|}{$\begin{array}{c}\text { Collective } \\
\text { agreements }\end{array}$} \\
\cline { 4 - 8 } & & $\mathbf{N}^{\circ}$ & $\mathbf{\%}$ & $\mathbf{N}^{\circ}$ & $\mathbf{\%}$ & $\mathbf{N}^{\circ}$ & $\mathbf{\%}$ \\
\hline $50-99$ & 1,082 & 288 & 27 & 261 & 26 & 243 & 23 \\
\hline $100-249$ & 882 & 456 & 52 & 389 & 46 & 359 & 41 \\
\hline Moe than 249 & 632 & 531 & 84 & 511 & 82 & 469 & 74 \\
\hline Total & 2,596 & 1,275 & & 1,161 & & 1,071 & \\
\hline
\end{tabular}

Source: Benyó, B. A.: munkavállalói részvétel intézménye: az üzemi tanácsok helyzete Magyarországon, (Institution of Emplyees' Participation: Situation of Works Councils in Hungary), PhD Dissertation, Budapest: Budapest University of Economic Sciences and Business Administration - Department of Social Policy and Sociology, p.75.

\subsection{Affiliations and organisations of employers: national and european level comparison}

The existence and activities of employers' interest representative associations (organisations) are strongly influencing singular or multi-employers' bargaining and, consequently, the coverage rate of collective agreements. The organisational building up of employers' associations varies across the countries participating in the Leonardo Project. In relation with the organisations of employers, it is worth calling attention to the dual structure of these organisations. The single structure operating at cross-industry level exists in Belgium, France, Slovakia, Spain and in the UK. Contrary to the previous countries, Germany represents a national case with a division of tasks and responsibilities - at the national level - between collective interest 
representation (i.e. that are partners in collective bargaining) and trade interests (i.e. chamber of trade and commerce, etc.). ${ }^{3}$

The most radical restructuring process took place in the Post-socialist economies during the 1990s following the collapse of state-socialist 'regime'. Aftermath the privatisation, in relation to the deconstruction-decentralisation of the former mono-system of employers' organisations, a proliferation of employers' organisations have taken place. ${ }^{4}$ As a result of this process, we may register three employers' organisations in Poland and six or more in Hungary. Among various problems related to the role of business and employers' associations in the New Member States, we would like to stress the underdevelopment of sector level bargaining: 'This is due to the fact that in most of these countries sectoral employers' organisations are either weak and lack the necessary resources to participate or that they are denied the authority to conclude sectoral agreements on behalf of their members, as is often the case for instance in Hungary and in Poland. ${ }^{5}$ However, in Hungary, to overcome the lack of sector level social dialogue, an EU-funded (PHARE, 2001-2004) project was launched aimed to create autonomous sector (branch) level institution of social dialogue. This new institution within the Hungarian LRS would have a role to support sector level consultations among the social actors, increasing the number of sector level collective agreements. ${ }^{6}$

Evaluating the representation of employers' interest at EU level, the 'Union des Industries de la Communauté Européenne' (UNICE - since 1987 this organisation fulfils the role of 'Industrial and Employers' Association') covers almost all the main national cross-industry confederations of competitive (private) sector employers. In addition to the EU-15 countries, majority of the

3 Note: in some region, for instance in Bavaria, the two structures have been integrated. In this relation, it is necessary to mention that rationalisation process have been identified at the levels below the peak associations. This process includes on one hand mergers of employers' organisations and trade interests, and on the other hand integration of employers' association representing neighbouring sectors (e.g. notable number of mergers at the levels below of peak associations were reported in the UK). Source: Industrial Relations in Europe, 2004.:26.

4 In relation to the membership of employers' organisations, we would like to note the followings: not counting countries where the membership of employers' organisation is obligatory by the law, the average organisation rate is $60 \%$. Though, this average hides significant differences across countries participating in the Leonardo Project. For example, extremely organisation rates $(70 \%$ or more) were found in Belgium, France and Spain. Below the average $(40 \%)$ characterises the British employers' organisations. In some countries no data were available (e.g. Hungary, Poland).

5 Source: Industrial Relations in Europe, 2004.: 27.

6 Foglalkoztatáspolitikai és Munkaügyi Minisztérium (Ministry for Employment Policy and Labour), 2004: 5. 
NMS countries also have representation in this organisation (e.g. Hungary, Poland and Slovakia). Continuing the distinctions we made between employers' organisations and trade association, the UNICE acts as both types of organisation. In other words, it is engaging in social dialogue and negotiations with European Trade Union Council (ETUC) and as a trade association promoting its members' interests in influencing EU decision-makers on great variety of issues (e.g. see the debate on the Chinese textile quota in the European $\mathrm{U}$ Reviewing the situation of European level representation of employers' organisations in the SME sector, it is important to stress the following characteristics. There is a separate European-level institution representing the particular interests of SME sector: European Association of Craft and Small and Medium-sized Enterprises (UEAPME). This European-level body representing SMEs has 77 national member organisations in EU-15 countries. In the NMS only Hungary is admitted as a full member. All other NMS has only observer status (see in details Table 5.!)

Table 5. Europe's business and employers' association affiliation, organisation rates and participation in social dialogue

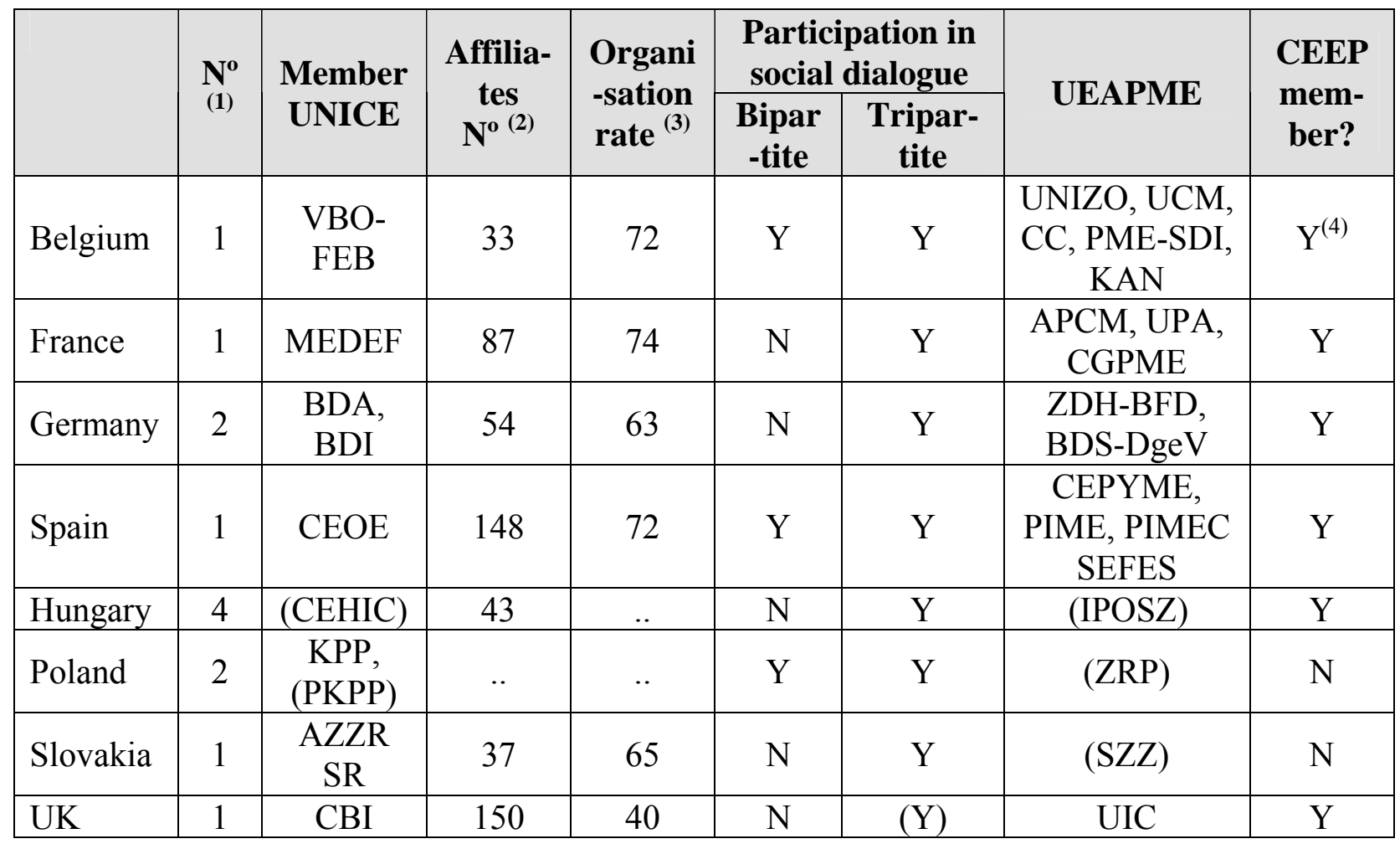

NB: (1) General associations, without organisations specialising in representing agriculture, horticulture and fishery; cooperatives; SMEs, financial enterprises, and nationalised firms or local government; public sector, organisations representing public firms or special sectors, such as finance and banking. (2) Only sectoral affiliates or companies, without regional affiliates. (3) Expressed as a percentage of wage and salaried employees working in organised firms. Members with observer status between brackets. (4) Benelux. 
Sources: Reports and websites of UNICE, CEEP and UEAPME; supplemented with information from F.Traxler, S. Blaschke and B. Kittel (2001), National labour relations in internationalised markets, op.cit., and the Institut des Sciences du Travail of the Université Catholique de Louvain, Monographs on the situation of social partners in the candidate countries, Brussels, December 2003, a research project conducted on behalf of the Employment and Social Affairs DG of the European Commission. Quoted by Industrial Relations in Europe, 2004: 25. Table 5. is an edited version of the original one containing data only for countries involved in the Leonardo Project

\subsection{Collective bargaining and social dialogue: particular focus on wage bargaining}

This section reviews the key institutions regulating the relations between employers (employers' organisations) and employees' interest representative associations (trade union). In this relation, we have to make distinction between the following institutions:

\section{Collective bargaining}

\section{Consultation}

\section{Social dialogue}

In dealing with these institutions, we intend to focus mainly on the issues of collective bargaining (for example: coverage rate, legal extension of collective agreements, wage bargaining, etc.) and the role of tripartite bodies as a particular form of social dialogue. In the previous section we have already given details of various features of works councils as a key form of consultation; therefore this section does not deal with this form of collective representation.

Evaluating the practice of collective bargaining, there are noticeable differences in the conditions and the impacts of collective bargaining both in EU-15 and NMS countries involved in the Leonardo Project.

\section{Box 2. ILO definition of Collective Agreement}

ILO Convention No 98 of 1949 defines collective bargaining as 'voluntary negotiations between employers or employers' organisations and workers' organisations, with a view to the regulation of terms and conditions by collective agreements'. Collective bargaining is thus a rulemaking process based on joint decisions between independent organisations. When successful, it results in agreements which specify the collective rules and conditions applying to employment and employment relations in firms, i.e. conditions of work and rules governing the relations between employees and managers. Additionally, agreements usually also define the relationship between the negotiating organisations, for instance with regard to the renewal of agreements, dispute procedures, peace obligations, recognition and facilities. All this has no counterpart in individual bargaining between workers and managers.

Source: Industrial Relations in Europe, 2004, 29.

Prior to the presentation of the coverage rate of collective bargaining both at European and country levels, we have to raise briefly some methodological problems. The collective bargaining coverage rate operationally refers to the number of employees covered by a collective agreement (CA) as a proportion of 
all wage- and salary-earners employed. It is a widely accepted view among the Labour Relations experts that bargaining coverage rate indicates the real bargaining strengths of the trade unions concerning the employment and working conditions (the union density rate is reflecting only the potential bargaining power of organised employees).

There are several important factors influencing the collective bargaining coverage rate and its measurement (see in detail these methodological problems, in Industrial Relation in Europe, 2004: 30.). Table 6 illustrates the national (aggregate) rates of collective bargaining coverage, the employers' organisations' and union

Table 7. Collective bargaining coverage, employers' organisations and union density density.

\begin{tabular}{|l|c|c|c|c|c|c|c|c|c|c|}
\hline & $\mathbf{1 - 1 0}$ & $\mathbf{1 1 - 2 0}$ & $\mathbf{2 1 - 3 0}$ & $\mathbf{3 1 - 4 0}$ & $\mathbf{4 1 - 5 0}$ & $\mathbf{5 1 - 6 0}$ & $\mathbf{6 1 - 7 0}$ & $\mathbf{7 1 - 8 0}$ & $\mathbf{8 1 - 9 0}$ & $\mathbf{9 1 - 1 0 0}$ \\
\hline Belgium & & & & & & $\mathrm{U}$ & & $\mathrm{E}$ & & Cov \\
\hline France & $\mathrm{U}$ & & & & & & & $\mathrm{E}$ & & Cov \\
\hline $\begin{array}{l}\text { Ger- } \\
\text { many }\end{array}$ & & & $\mathrm{U}$ & & & & $\begin{array}{c}\text { Cov, } \\
\mathrm{E}\end{array}$ & & & \\
\hline Spain & & $\mathrm{U}$ & & & & & & $\mathrm{E}$ & Cov & \\
\hline Hungary & & $\mathrm{U}$ & & Cov & & & & & & \\
\hline Poland & & $\mathrm{U}$ & & & $\begin{array}{c}\text { Cov, } \\
\mathrm{E}\end{array}$ & & & & & \\
\hline Slovakia & & & & $\mathrm{U}$ & $\mathrm{Cov}$ & & & & & \\
\hline UK & & & $\mathrm{U}$ & $\begin{array}{c}\text { Cov, } \\
\mathrm{E}\end{array}$ & & & & & & \\
\hline
\end{tabular}

NB: Cov $=$ bargaining coverage non-standardised; $\mathrm{E}=$ employer organisation rate (private sector); U = Union density rate. Quoted by Industrial Relations in Europe 2004: 31. Table 7 is an edited version of the original one containing data only for countries involved in the Leonardo Project.

When comparing the collective bargaining coverage rates with the union density rates, we identified the following patterns:

1 The collective bargaining coverage rate is not only more stable but at least twice as high as the union density rate. This difference calls attention to the careful interpretation of the union density rate in relation to strengths and mobilisation capacity of trade union.

2 Comparing the coverage rate of the EU-15 and NMS countries we found a striking gap: the EU-15 countries - in spite of their massive variation from $100 \%$ (France) to $36 \%$ (the UK) - the aggregated average rate is rather high (weighted average rate for EU-15 countries is $78 \%$ ). In the case of NMS - with the exception of Slovenia (100\%) - a decline in collective bargaining coverage has been identified during the transformation of 1990s and today. For example, according to "a recent statistical study of the Ministry of Employment and Labour in Hungary reported a further 5-point drop in the coverage rate from 45 
to $40 \%$ between 2001 and 2002 (unadjusted rates). According to the study, this suggests that private-sector employers may be withdrawing from wage negotiations and that the current company bargaining structure provides no stable framework." (Industrial Relations in Europe, 2004: 32.) ${ }^{7}$

3 In relation to the lower collective bargaining coverage rate in the NMS countries, we have to note that the declining coverage rate was especially strong in the so-called post-socialist economies. This decline was particularly deep in comparison with the $100 \%$ coverage rate of the state-socialist firms based on the obligatory membership of both trade union and chamber of commerce, trade and industry.

\subsubsection{Role of extension in collective bargaining}

It is not unusual for employers to voluntarily extend negotiating agreements to both unionised and non-union workers. This non-discriminatory extension of collective agreements to employees working in the same firms is recommended as a 'best practice' by the ILO Recommendation N 91 of 1951. The following box describes the legal or administrative regulations concerning the extension of negotiated agreements to both union and non-union members.

There are great variations in the procedures related to the extension of collective agreements. Public authorities, such as Ministries of Labour, play a decisive role in initiating the extension in France, in Spain and to some extent in Slovakia. 'Several countries have established minimum requirements for extension, most commonly minimum rates for coverage of the relevant agreement prior to extension ${ }^{8}$ - this practice is used for example in Germany, Hungary and Spain. Table 8 summarises the various procedures related to the legal and administrative regulation of extension of collective agreements.

A 2002 EIRO study provides a general view on the practice of extension of collective agreements. The key lessons of this survey should be summarised in the following way: high stability and continuity of extension provisions are characterising the EU-15 and some of the candidate countries. Before presenting interesting cases covering some of the countries participating in the Leonardo Project, we have to indicate that the last years were characterised by intensified debates on the extension of collective bargaining (e.g. France, Germany, Hungary and Poland).

7 It is necessary to mention that in many cases employees are coping with the problem of the delays in payment, underpayment, even where collective agreements exist. In Poland, for example, according to one government survey two thirds of audited companies in breach of contract including both small and large sized companies (Industrial Relations in Europe, 2004: 32.)

8 Industrial Relations in Europe, 2004: 34. 


\section{Box 3. ILO recommendation on the extension of collective agreement}

(1) Where appropriate, having regard to established collective bargaining practice, measures, to be determined by national laws or regulations and suited to the conditions of each country, should be taken to extend the application of all or certain stipulations of a collective agreement to all the employers and workers included within the industrial and territorial scope of the agreement.

(2) National laws or regulations may make the extension of a collective agreement subject to the following, among other, conditions;

(a) that the collective agreement already covers a number of the employers and workers concerned which is, in the opinion of the competent authority, sufficiently representative;

(b) that, as a general rule, the request for extension of the agreement shall be made by one or more organisations of workers or employers who are parties to the agreement;

(c) that, prior to the extension of the agreement, the employers and workers to whom the agreement would be made applicable by its extension should be given an opportunity to submit their observations.

Source: http://www.ilo.org/ilolex/english/recdisp1.htm

\section{Table 8. Legal or administrative extension of collective agreements}

\begin{tabular}{|c|c|}
\hline Belgium & $\begin{array}{l}\text { Extension is automatic if agreements are signed by all parties in Joint } \\
\text { Industry Councils or in the National Labour Council. If not, the Ministry can } \\
\text { extend multi-employer agreements by royal decree on application of one or } \\
\text { more bargaining parties. }\end{array}$ \\
\hline France & $\begin{array}{l}\text { On the request of one or more of the bargaining parties, addressed to the } \\
\text { National Commission on Collective Bargaining, the Minister can extend } \\
\text { agreements to entire sectors and/or enlarge agreements to different } \\
\text { geographical regions or other economic sectors. }\end{array}$ \\
\hline Germany & $\begin{array}{l}\text { On the application of one or more of the bargaining parties and approved by } \\
\text { a special committee for extensions, and if more than } 50 \% \text { of the workforce } \\
\text { is already covered, the Ministry can extend agreements to the entire sector. } \\
\text { Since } 1998 \text {, and only in the construction industry, the Ministry can extend } \\
\text { minimum wage provisions at its own initiative. }\end{array}$ \\
\hline Spain & $\begin{array}{l}\text { Extension is automatic throughout the agreement's domain if signed by a } \\
\text { majority of the representatives of each party to the agreement. Upon request } \\
\text { by unions and/or employers, the Ministry can enlarge the agreement in cases } \\
\text { where no bargaining exists. }\end{array}$ \\
\hline Hungary & $\begin{array}{l}\text { On application of one or more of the bargaining parties and after } \\
\text { consultation with the subcommittee of the National Interest Reconciliation } \\
\text { Committee, the Ministry can extend agreements to the entire sector. } \\
\text { Applicants must provide proof of their representativity in the sector } \\
\text { concerned. }\end{array}$ \\
\hline Poland & $\begin{array}{l}\text { The Ministry can extend multi-employer agreements to cover unaffiliated } \\
\text { employers in a particular sector, if considered 'a vital social interest'. }\end{array}$ \\
\hline Slovakia & $\begin{array}{l}\text { On the application of one or more of the bargaining parties and } \\
\text { recommended by a special tripartite committee for extension, the Ministry } \\
\text { can extend agreements to employers with similar business activities and } \\
\text { economic and social conditions }\end{array}$ \\
\hline UK & $\begin{array}{l}\text { No practice of extension of private-sector wage agreements. All extension } \\
\text { provisions were abolished in the } 1980 \text {. }\end{array}$ \\
\hline
\end{tabular}


Source: F.Traxler and M. Behrens (2002), 'Collective bargaining coverage and extension procedures'; EIRO - Eironline; OECD (2004), 'Wage setting institutions', in Employment Outlook, Paris, 17. Quoted by Industrial Relations in Europe, 2004: 33. Table 8 is an edited version of the original one containing data only for countries involved in the Leonardo Project.

\subsubsection{Changing forms of coordination in the bargaining process: the case of wage bargaining}

From the 1990s, the pattern of decentralisation became the mainstream feature of industrial relations. Under the pressure of global competition, the restructuring process of companies on a national, European or global level is further driven by the utilisation of fast changes in the global value chain. European integration speeded up in the last year $\left(1^{\text {st }}\right.$ May 2004), in particular making it possible for companies to re-orientate their activities directly at a supranational market. Costs can be cut by selecting the most favourable locations using such enablers as ICT (e.g. through outsourcing or delocalisation of generic business functions). Companies are focusing on their core activities and seeking to outsource others. Cooperation between small and medium-sized companies can be facilitated both by technological and social innovations. These are tools to improve both employment and organisational flexibility. Unfortunately, in the flexibility debate relatively little attention was paid to the role of wage bargaining. ${ }^{9}$ However, wage issues had and continue to have a central importance in the debates and wage-related conflicts often occurring in relation to employers' and employees' everyday working practices.

However, it would be important not to exaggerate this underestimated role of Labour Relations. In the last quarter of the century, in many countries bargaining on the working time reduction represented the trend of decentralisation. Beside the working time reduction, the wage negotiations are shifting into the focus of decentralisation of collective bargaining. The next quotation describes well the underlying economic, technological and organisational drivers/enablers favouring the decentralisation of Labour Relations: “(...) internationalisation, technological and organisational change, multi-tasking, teamwork and client-related work processes have made standardised solutions, negotiated for entire sectors, less feasible and efficient (...) it has become more important for internationally competing firms to have the freedom to react speedily to wage competition from foreign firms. The introduction of performance related pay, and payment by results, has also supported the demand for company level bargaining." (Industrial Relations in Europe, 2004: 36-37.)

9 The works representing the exceptions are the followings: Crouch/Traxler (1995), Lindbeck/Snower (2001), Yamamura/Streeck (2003). 
Table 9 reviewing the levels and duration of collective bargaining in the last surveyed year (2003) indicates that sector or branch level collective bargaining completed with the firm level bargaining dominate in nearly every second European countries. The so-called multi-employer collective bargaining at sector level still dominates the wage-setting in the EU-15 countries. There are big differences concerning the importance of various bargaining levels within the national bargaining structures. In the EU-15 countries involved in the Leonardo Project, the cross-industry level wage bargaining was found in Belgium and the company level bargaining was dominant in France and in the UK. As concerning the UK, we have to note that this is the only country from among the EU-15 countries where almost all bargaining takes place at firm level. Similarly to the British case, in the new Member States, the company level bargaining dominates with the exception of Slovakia (see in details the Table 9!).

Beside the forms of the decentralisation of wage bargaining, there are other tools of wage regulation which may improve the flexibility of employment and knowledge use. Various forms of coordination may facilitate decentralisation and improve flexibility of labour relation system: "Coordination based on shared understanding and mutual trust may be more important than centralisation of wage-setting. This is perhaps the strongest lesson from the experience of social pacts - many of which were fully unexpected and negotiated in rather fragmented and decentralised wage-setting structures. A shared understanding of the economic and social context, and of key mechanisms driving growth, productivity and employment, greatly increases the probability of wagebargaining being conducted in a cooperative way, in which each party has an eye on their own long-term self-interest and the common good, and not only to their short-term interest or purely sectional concerns." (Industrial Relations in Europe, 2004: 44.)

Evaluating the types of coordination, we may use the following scale. One extreme of the scale represents the 'explicit' coordination. However, this type of coordination covers various forms: firstly, coordination exists between peak organisations of either trade unions or employers materialised in agreements at national or sectoral level (i.e. bipartite interest concertation). Secondly, explicit coordination may develop in cases when social partners agree to behave according to commonly accepted rules with or without government participation (i.e. tripartite interest concertation). On the middle of the scale of coordination of wage bargaining are located various forms of 'implicit' coordination. The strongest form of this type of coordination is based on the norm or trend-setting role of a leading trade union or employers' group dominating one sector at national or regional level. In other cases (which represent the weaker versions of 'implicit' coordination), social partners intend to inform each other of their ambitions for the wage-setting. When social partners rely on this form of coordination, they do not wish either to set a clear guideline or to reach 
agreement on wage related issues. The fifth type equals no coordination. Table 10 illustrates the location of the countries participating in the Leonardo project on the scale of wage-bargaining coordination.

Table 9. Levels of wage bargaining and duration of collective agreements, 2003

\begin{tabular}{|l|c|c|c|c|}
\hline & National & Sector & Company & $\begin{array}{c}\text { Duration of } \\
\text { contracts (year) }\end{array}$ \\
\hline Belgium & $* * *$ & $* *$ & $*$ & 2 \\
\hline France & & $*$ & $* * *$ & $2 ?$ \\
\hline Germany & & $* * *$ & $* *$ & $1-2$ \\
\hline Spain & $*$ & $* *$ & $* *$ & $2-3$ \\
\hline Hungary & $*$ & $*$ & $* * *$ & 2 \\
\hline Poland & & $*$ & $* * *$ & Variable \\
\hline Slovakia & $*$ & $* *$ & $* *$ & 2 \\
\hline UK & & & $* * *$ & Variable \\
\hline
\end{tabular}

NB: $* * *=$ principle or dominant bargaining level; $* *=$ important but not dominant level; * = existing level of bargaining. Sources: Adapted from EIRO publications. Quoted by Industrial Relations in Europe, 2004:, 39. Table 9. is an edited version of the original one containing data only for countries involved in the Leonardo Project.

\section{Table 10. Coordination of wage bargaining}

\begin{tabular}{|l|l|c|c|}
\hline & Types of coordination \\
\hline Belgium & $\begin{array}{l}\text { Explicit coordination in National Labour Council, little sectoral } \\
\text { coordination }\end{array}$ & 4 & 0.61 \\
\hline France & $\begin{array}{l}\text { Irregular implicit coordination through pattern-setting in the } \\
\text { public sector and nationalised industries }\end{array}$ & 1.5 & 0.37 \\
\hline Germany & $\begin{array}{l}\text { Implicit coordination through comprehensive sectoral bargaining } \\
\text { and pattern-setting }\end{array}$ & 3 & 0.43 \\
\hline Spain & $\begin{array}{l}\text { Some explicit coordination between confederations of unions and } \\
\text { employers in recent years and weak pattern-setting in sectoral } \\
\text { bargaining }\end{array}$ & 3 & 0.48 \\
\hline Hungary & $\begin{array}{l}\text { Some national coordination through the tripartite body, no sectoral } \\
\text { coordination }\end{array}$ & 2 & 0.28 \\
\hline Poland & No national or sectoral coordination & 1 & 0.21 \\
\hline Slovakia & No national coordination since 2000, some sectoral coordination & 2 & 0.31 \\
\hline UK & No national or sectoral coordination & 1 & 0.19 \\
\hline
\end{tabular}

NB: $5=$ Explicit coordination between and within the peak association of unions and employers, through agreements at the national and sectoral level; $4=$ Explicit coordination between peak federations through agreements at national level only, or implicit coordination in confederations (unions or employers) at the national and sectoral level; 3 = Implicit coordination through synchronisation of sectoral bargaining and pattern-setting; 2 = Some coordination through supervision and weak, irregular or incomplete pattern-setting; $1=$ No coordination at the national or sectoral level. Weighted with coverage rate.

Quoted by Industrial Relations in Europe, 2004: 45. Table 10 is an edited version of the original one containing data only for countries involved in the Leonardo Project. 
The findings of the Table 10 call attention to the following three groups of the countries in relation to the wage-bargaining coordination. Only Belgium maintained or reintroduced some forms of explicit coordination at the national level. In Germany and Spain - where central agreements have set guidelines for wage conduct since 2001 - the implicit coordination characterises the relations between social partners. Patterns setting practice exists in Germany and the implicit coordination characterises the French wage-bargaining coordination. Finally, in the UK, similarly to Poland, both national or sectoral levels coordination are missing.

It is worth noting that: "The tradition of national wage agreements, existing in Slovakia, faltered in the late 1990s and the last such agreement was concluded in 2000. Attempts to reach agreement in Poland stalled in 2003. In Hungary, however, there have been fresh initiatives. Usually the legal status of a national agreement is a non-binding recommendation to lower level bargainers, but there is little coordination, within or between confederations, or in sectors, to put pressure behind such recommendations or monitor their follow-up." (Industrial Relations in Europe, 2004: 46.)

\section{Annex 1 LEONARDO Community Vocational Training Action Programme,}

(2003-3448/001-001-LE2_OREF, Contract start date: 01. October 2003,

Duration 36 Months (01. 10. 2003 - 30. 09. 2006)

\section{Partners:}

Belgium:

EHSAL, Brussels

France:

Université Paris X, Nanterre

Germany:

Wismar University; Wismar

Hungary:

Institute of Sociology, Hungarian Academy of Sciences; Budapest

Poland: Institute of Labour and Social Studies; Warsaw

Spain: UNED; Madrid

Slovakia: Institute for Sociology, Slovak Academy of Sciences; Bratislava

UK: $\quad$ University of Luton, Luton 


\section{References}

Addison, J. T/Schnabel, C. (2003): International Handbook of Trade Unions. Cheltenham: Edgar Elgar.

Adler, P./Kwon, S.W. (2000): Social Capital: the Good, the Bad and the Ugly, (in) Lesser, E. L. (ed) Knowledge and Social Capital (Foundations and Applications). Oxford: Butterworth Heinemann.

Benyó, B. (2004): A munkavállalói részvétel intézménye: az üzemi tanácsok helyzete Magyarországon, (Institution of Employees' Participation: Situation of Works Councils in Hungary), PhD Dissertation, Budapest: Budapest University of Economic Sciences and Business Administration - Department of Social Policy and Sociology.

Boeri, T./Brugiavini, A./Calmfors, L. (eds.): The Role of the Trade Unions in the $21^{\text {st }}$ Century. Oxford: Oxford: University Press.

Charley, M:/Baradel, A./Welz, Ch. (2004): Works Councils - Workplace Representation and Participation Structures, in: EIRO Thematic Features. Dublin: European Foundation for the Improvement of Living and Working Conditions.

Crouch, C. J./F. Traxler, F. (eds.) (1995):, Organised Industrial Relations in Europe, in: What future?, Hants, Vermont.

Developments in Industrial Actions: 2000 - 2004, (http://www.eiro.eurofound.eu.int/2005/06/update/tn0506101u.htm).

Ebbinghaus, B./Visser, J. (2000): The Societies of Europe, in: Trade Unions in Western Europe since 1945,.London: Plagrave.

Ebbinghaus, B./Visser, J. (1999): When Institutions Matter: Union Growth and Decline in Western Europe, 1950-1995,in: European Sociological Review, Vol. 15.

EIRO (1999): Industrial relations in SMEs (http://www.eiro.eurofound.eu.int/1999/05/ study/tn9905201s.html - date of downloading: $12^{\text {th }}$ September 2005).

Employment Relations in Micro and Small Enterprieses in the EU - Literature Review (2002) Dublin: European Foundations for the Improvement of Living and Working Conditions - Main Results.

European Foundation for the Improvement of Living and Working Conditions and Its European Industrial Relations Observatory Online (Euroline), (http://www.eiro.eurofound).

Foglalkoztatáspolitikai és Munkaügyi Minisztérium (2004): Ágazati párbeszéd bizottságok Magyarországon (Sector level social dialogue committees). Budapest: Foglalkoztatáspolitikai és Munkaügyi Minisztérium.

Industrial Relations in Europe 2004, EC DG for Employment and Social Affairs, Unit D1, Luxemburg: Office for Official Publications of the European Communities.

Industrial Relations in SMEs, EIRO (http://www.eiro.eurofound.eu.int/1999/05/study/ tn9905201s.html).

Lesser, E. L. (2000): Leveraging Social Capital in Organizations, (in) Lesser, E. L. (ed) Knowledge and Social Capital (Foundations and Applications). Oxford: Butterworth Heinemann. 
Lindbeck, A./Snower, D. J. (2001): Centralised Bargaining and Reorganised Work: Are they Compatible?, in: European Economic Review, Vol. 45.

Makó, Cs. (2001): A magyar munkaügyi kapcsolatok duális karaktere, (A munkavállalói részvétel intézménye és az európai perspektíva), (The Dual Character of Hungarian Labour Relations - Institution of Employees' Participation in a European Perspective), in: Társadalomkutatás, (2001), 3-4, 145-169.

Makó, Cs./Novoszáth, P. (1995): Employment Relations in Multinational Companies: the Hungarian Case, (in) Dittrich, Schmidt,E./ Whitley,G.(1995), in: Industrial Transformation in Europe: Process and Context. London: Sage Publication, 255-277.

Makó, Cs./Novoszáth, P./Veréb, Á. (1998): Átalakuló munkaerőfelhasználási minták és a vállalati munkaügyi kapcsolatok, (Munkavállalói beállítottságok nemzetközi összehasonlításban), (Changing Patterns of Manpower Use and Firm-Level Labour Relations, Workers' Attitude in an International Comparison). Budapest: Aula Kiadó, 208.

Makó, Cs. - Simonyi, Á. (1997) Inheritance, Imitation and Genuine Solutions, (Institution Building in Hungarian -Labour Relations), in: Europe-Asia Studies,(1997) Vol. 49. No. 2. March, 221-244.

Makó, Cs./Simonyi, Á. (2003): A munka és párbeszéd új paradigmái (New Paradigmes of Work and Social Dialogue). Budapest: National Employment Fund.

Neumann, L. (2002): EIRO Comparative Study on Collective Bargaining Coverage and Extension Procedures - Case of Hungary. Budapest: Insitute of Labour - Ministry of Employment and Labour.

Neumann, L. (2003): The Impact of European Legislation on an Accession Country's Labour Relations (The Case of Hungarian Transposition of Undertaking Directive), Berlin: Paper presented for IIRA $13^{\text {th }}$ World Congress.

Neumann, L. (2005): Towards Trade Union Strategy for Decent Work - the Hungarian Case. Budapest: Institute of Labour Research, Mimeo.

Read, I. (2005): Employers' Association and SME Interests in the UK. London: Metropolitan University - Working Lives Research Institute.

Rogers, J. Streeck, W. (eds.) (1995): Works Councils, Consultation, Representation and Cooperation in Industrial Relations. Chicago: University of Chicago Press.

Schienstock, G. (2004): From path dependency to path creation: a new challange to the systems of innovation approach, in Schienstock, G. (ed.) Embracing the Knowledge Economy: The Dynamic Transformation of the Finnish Innovation System. Cheltenham, UK: Edward Elgar Publishing Ltd, 3-27.

Schulte, B./Guillén, M./Tsakloglou, P./Katrougalos, G./Wilthagen, T./Bradsaw, J./Anxo, D./Ericson, T. (2003): Flexibility and Social Protection - European Foundation for the Improvement of Living and Working Conditions. Luxemburg: Office for Official Publications of the European Communities.

Thelen, K./Kune, I. (2003): The Future of Nationally Embedded Capitalism, Industrial Relations in Germany and Japan, In: Yamamura - Streeck (eds.) The End of Diversity. Prospects for German and Japanese Capitalism, Ithaca. N.Y.: Cornell University Press.

Traxler, F. (2003): Bargaining, State Regulation and the Trajectories of Industrial Relations, in: European Journal of Industrial Relations, No. 9,141-161. 
Traxler, F. (2003): Bargaining (De)Centralization, Macroeconomic Performance and Control over the Employment Relationship, in: British Journal of Industrial Relations, 41,1-28.

Traxler, F. (2003): Bargaining Institutions and the Monetary Regime: A Cross-national Comparison and its Implications for European Monetary Union, in: Journal of European Public Policy, 10, 596-615.

Traxler, F./Behrens, M: (2002): Collective Bargaining Coverage and Extension Procedures, EIRO - Eironline; Wage-Setting Institutins, Employment Outlook. Paris, no. 17.

Traxler, F./Blaschke, S./Kittel, B. (2001): National Labour Relations in Internationalised Market. A Comparative Study of Institutions, Change and Performance. Oxford: Oxford University Press.

Yamamura, ,K./Streeck, W. (eds.) (2003): The End of Diversity. Prospects for German and Japanese Capitalism, Ithaca. N.Y.: Cornell University Press.

Van Gyes, G. (2003): Industrial Relations as a Key to Strengthening Innovation in Europe, EC Directorate-General for Enterprise - EUR 17060, Luxemburg: Innovation Papers No 36.

Vielle, P./Walthery, P. (2003): Flexibility and Social Protection, The European Foundation for the Improvement of Living and Working Conditions. Luxembourg: Office for Official Publications of the European Communities.

Visser, J. (2002): Why Fewer European Workers Join Unions. A Social Customs Explanation of Membership Trends, in: British Journal of Industrial Relations, Vol. 40.

Warhurst, Ch. (2005): The UK Union Learning Fund - A Briefing Note for the Deputy Minister of Labour. Hungary. Glasgow: Scottish Centre for Employment Research Department of Human Resource Management University of Strathclyde.

Wim Kok (2003): Report of the Employment Workforce, Jobs, Jobs, Jobs: Creating More Employment in Europe. Luxemburg: Office for Official Publications of the European Communitie. 